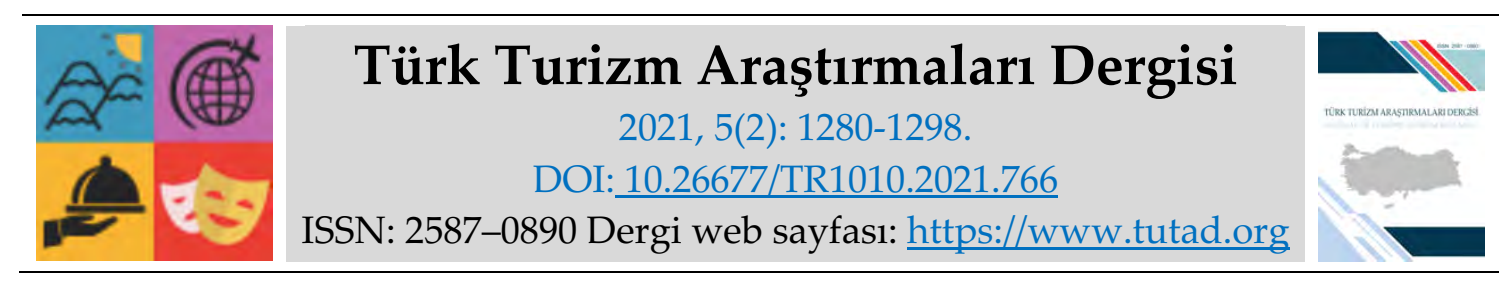

ARAȘTIRMA MAKALESI

\title{
Gastronomi Turist Taksonomisi
}

Öğr. Gör. Gülden KURT, Muğla Sıtkı Koçman Üniversitesi, Muğla Meslek Yüksekokulu, Muğla, e-posta: guldenkrt@gmail.com

ORCID: https://orcid.org/0000-0001-6275-5204

Doç. Dr. Reyhan ARSLAN AYAZLAR, Muğla Sıtkı Koçman Üniversitesi, Turizm Fakültesi, Muğla, e-posta: reyhanayazlar@gmail.com

ORCID: https://orcid.org/0000-0002-9546-9412

Öz

Destinasyona ait kültürü deneyimlemenin yeni bir yolu olarak gastronomi turizmi son yıllarda yükselişe geçen bir turizm türüdür. Bu çalışmada 2015 yılında UNESCO tarafından yaratıcı şehirler ağı listesinde 'Gastronomi Şehri' olarak kabul edilen Gaziantep ilini gastronomi amaciyla ziyarete gelen yerli turistlerin taksonomisini oluşturmak amaçlanmıştır. Bu kapsamda Gaziantep Büyükşehir Belediyesi iştiraki ile kurulan Mutfak Sanatları Merkezi'ne gelen ziyaretçilere odaklanılmıştır. Araştırmada Q metodoloji kapsamında literatür incelemesi sonucu oluşturulan $Q$ dizgi kartları katılımcılara sunulmuştur. Araştırma sonunda 36 katılımcıdan elde edilen geçerli veri seti $Q$ metodolojisi yoluyla analiz edilmiş olup "müdavim turist, yöresellik arayanlar, özgün turist, yenilik arayanlar" olmak üzere dört farklı gastronomi turisti ortaya konulmuştur. Müdavim turistler önceden deneyimledikleri lezzeti arayan turistler iken; yöresellik arayanlar yöresel yiyeceklere ve bunlarla ilgili tanıtıcı bilgilere odaklanan turistlerdir. Özgün turistler gidilen destinasyonun kültürel özelliği olarak yiyecek içeceklere önem verirken; yenilik arayanlar gastronomiyi günlük rutinden kaçış olarak görmektedir.

Anahtar Kelimeler: Gastronomi Turizmi, Q Metot, Taksonomi, Gaziantep.

Makale Gönderme Tarihi: 10.02.2021

Makale Kabul Tarihi: 04.06.2021

\section{Önerilen Atıf:}

Kurt, G. ve Arslan Ayazlar, R. (2021). Gastronomi Turist Taksonomisi, Türk Turizm Araştırmaları Dergisi, 5(2): 1280-1298.

(c) 2021 Türk Turizm Araştırmaları Dergisi. 


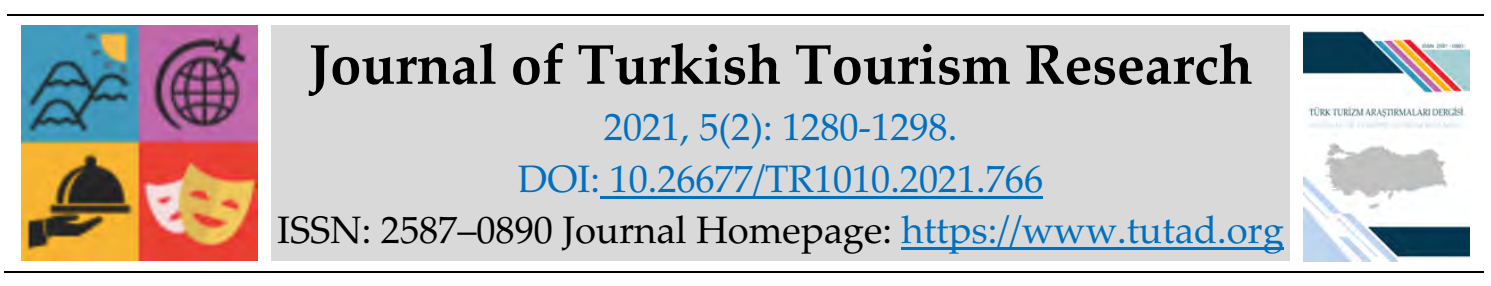

RESEARCH PAPER

\title{
Taxonomy of Gastronomy Tourist
}

Lecturer Gülden KURT, Muğla Sıtkı Koçman University, Muğla Vocational School, Muğla, email: guldenkrt@gmail.com

ORCID: https://orcid.org/0000-0001-6275-5204

Associate Prof. Dr. Reyhan ARSLAN AYAZLAR, Muğla Sıtkı Koçman University, Faculty of Tourism, Muğla, e-mail: reyhanayazlar@gmail.com

ORCID: https://orcid.org/0000-0002-9546-9412

\begin{abstract}
Gastronomy tourism has been a rising trend as a way to experience destination culture and taste food and beverages incidental to destination. The aim of this study is using taxonomy to group the tourists who visit Gaziantep come here and whose primary purpose is gastronomic tourism. For this purpose, based on the subjective ideas and perceptions of tourists, it is aimed to reveal groups with similar ideas through the $Q$ method. The valid data obtained from 36 participants constituting the research sample was analyzed through the $\mathrm{Q}$ methodology, which allows the combination of quantitative and qualitative methods. Based on the information obtained as a result of the study, four different gastro-tourists have been introduced: "regular tourist, local seekers, genuine tourist and novelty seekers". Regular tourists seek food and beverages which are familiar to them whereas local seekers are gastronomy tourists who look for local foods and introductory information about them. While genuine tourists give importance to food and beverages as a cultural feature of the destination, novelty seekers see gastronomy as an escape from daily routines.
\end{abstract}

Keywords: Gastronomy Tourism, Q Method, Taxonomy, Gaziantep.

Received: 10.02 .2021

Accepted: 04.06.2021

\section{Suggested Citation:}

Kurt, G. and Arslan Ayazlar, R. (2021). Taxonomy of Gastronomy Tourist, Journal of Turkish Tourism Research, 5(2): 1280-1298.

(C) 2021 Türk Turizm Araştırmaları Dergisi. 


\section{Giriş}

Motivasyon kavramı turist davranışlarını nelerin belirlediği sorusuna yanıt arayanların önemli çalışma alanlarından biri olmuş ve turizm alan yazınında sıklıkla çalışılan konular arasında yer almıştır. Kökleri tüketici motivasyonuna dayanan turist motivasyonu kavramını ilk çalışanlar arasında Pizam vd., (1979: 195) yer almakta ve yazarlar turist motivasyonunu "turistik bir etkinliğe katılmak için bireyleri yönlendiren bir dizi ihtiyaçlar" olarak tanımlamaktadır. Motivasyon, turistlerin satın alma kararını ve bu doğrultuda oluşturulan talebi anlamada önemli ipuçları sunmaktadır. Aynı zamanda destinasyonun rekabet üstünlüğü elde etmesi açısından da turistlerin seyahat motivasyonları etkili bir yöntem olarak karşımıza çıkmaktadır (Hudson, 2008).

Turistlerin motivasyonunun önemine paralel olarak çeşitli seyahat motivasyon kuramlarının ortaya çıtığı görülmektedir. Söz konusu kuramların köklerinin Maslow'un (1954) ihtiyaçlar hiyerarşisi kuramına dayandığını söylemek mümkündür. Bu kapsamda Pearce tarafından 1983 yılında geliştirilen seyahat kariyer basamağı kuramı karşımıza çıkmaktadır. Bu kuramda ihtiyaçlar hiyerarşisi kuramında olduğu gibi turistler, turizm hareketinde bir kariyer hedefi benimsemekte ve tecrübe ile birlikte artan ihtiyaçların giderilmesine yönelik bir hareket söz konusu olmaktadır (Ryan, 1998).

Literatürde seyahat motivasyonu ile ilgili ortaya çıkan kuramlardan bir diğeri Crompton (1979) tarafından geliştirilen itme çekme kuramı gelmektedir. Kurama göre itme faktörleri bireyin günlük yaşamının dışına çıkmasını tetikleyen unsurlar iken; çekme faktörleri gidilecek destinasyonun seçiminde önemli rol oynayan unsurlardır. Genel anlamda kaçış, dinlenme, yenilik, macera, sağlık, sosyal etkileşim arzusu itme faktörleri olarak değerlendirilirken; destinasyonun özellikleri ve kültürü, turistik yerler, güneş, deniz, prestij, ucuz ulaşım olanakları gibi unsurlar çekme faktörleri arasında göz önünde bulundurulmaktadır (Klonesky, 2002; Yoon ve Uysal, 2005; Caber ve Albayrak, 2016; Tellioğlu, 2021). İtme-çekme kuramının turizm alan yazınında sıklıkla kullanıldığı, bazı çalışmalarda her iki unsurun birlikte kullanıldığı, bazı çalışmalarda ise yalnızca itme ya da çekme faktörlerinin araştırma kapsamına alındığ görülmektedir. Söz konusu çalışmaların farklı itme ve çekme faktörlerini belirlediğini söylemek mümkündür (Fodness, 1994; Sırakaya ve McLellan, 1997; Kim, Lee ve Klenosky 2003; Yoon ve Uysal, 2005; Yousefi ve Marzaki, 2012; Tellioğlu, 2021). Turistlerin neden seyahat ettiklerini anlamaya yönelik geliştirilen kuramlardan biri de kaçış-arayış modelidir. Iso-Ahola ve Mannell (1987) bu modelde iki boyutlu bir yaklaşım benimsemiş, rutinden ve stresli yaşamdan kaçış ile rekreatif etkinliklere katılarak psikolojik ödül arayışına girmenin turistleri motive ettiğini öne sürmüşlerdir (Hsu ve Huang, 2007). Seyahat motivasyonu kapsamında geliştirilen önemli kuramlardan bir diğeri de Plog'un allosentrizm ve psikosentrizm kuramıdır (1974). Her ne kadar Amerikan vatandaşlarının seyahat motivasyonunu ortaya çıkarmak amacıyla on altı havayolu şirketi ile yürütülen bir çalışma olması ve genellenmesi eleştirilse de (Kayar, 2008; Mo vd., 1993) alan yazında sıklıkla ele alınan motivasyon konuları arasında yer almaktadır. Kurama göre özgüveni yüksek, macera arayışı içinde olan bireyler allosentrik; özgüveni düşük ve güvenliğe daha fazla önem veren bireyler de psikosentrik olarak değerlendirilmektedir. Bu iki uçdeğer arasında yakın allosentrik, orta sentrik ve yakın psikosentrik olmak üzere farklı kişilik özellikleri de araştırmacı tarafından ortaya konmaktadır (Plog, 2001).

Seyahat motivasyonu farklı çalışmalarda çeşitli turizm türleri açısından incelenmiştir. Bu turizm türlerinden biri de gastronomi turizmidir. Turistlerin seyahat bütçelerinin $\% 25$ 'ini yeme içmeye ayırması ve bazı destinasyonlarda \%35'e kadar çıkabilmesi (World Food Travel Association, 2006) gastronomi turizmine yönelik çalışmaların artışını destekler niteliktedir. Buradan hareketle turizm alan yazınında gastronomi turizmine yönelik araştırmalarda artış olduğu görülmektedir. Araştırmaya konu olan gastronomi turistlerini Birleşmiş Milletler Dünya Turizm Örgütü (2012: 
7) tarafından "tatil planlarının bir kısmını ya da tamamını seyahat edilen destinasyona özgü yiyecek ve içecekleri tatmak ve gastronomi ile ilgili faaliyetleri gerçekleştirmek amacıyla seyahat edenler" şeklinde tanımlamaktadır.

Literatürde gastronomi turizmi alanında motivasyon çalışmalarına rastlanmaktadır. Mason ve Paggiaro (2009) yiyecek ve içecek festivallerine yönelik motivasyon unsurlarını inceledikleri çalışmalarında çekici faktörlerin katılımcıların algılarını önemli derecede etkilediği ve çekici faktörlerin ürünler ve bölge ile ilişkili olduğu sonucuna varmışlardır. Kim ve Eves (2012) kültürel deneyim, kişilerarası ilişki, heyecan, duyusal cazibe ve sağlık endişesi olmak üzere turistlerin yerel yemek motivasyonlarının beş boyutta toplandığını ifade etmişlerdir. Bayrakçı ve Akdağ (2015), yerli turistlerin yerel yemek tüketim motivasyonları arasında heyecan arayışı, kültürel deneyim, duyusal çekicilik ve sağlık beklentisi olduğunu belirlemişlerdir.

Gastronomi turizmi ulusal literatürde, turistlerin milliyet, eğitim ve yaş grupları gibi demografik özelliklerine göre gastronomi turizmine katılımları ve gastronomi ile ilgili görüşleri (Bekar ve Kılıç, 2014; Belpınar, 2014; Akbaba ve Kargiglioğlu: 2016) yabancı turistlerin gastronomi deneyimleri (Birdir ve Akgöl: 2015) gibi konularda ele alınmıştır. Gastronomi turist tipolojisini belirlemeye yönelik bir çalışma yürüten Şimşek ve Selçuk (2018) organikçi turist, yenilikçi turist, öğrenmeyi sevenler/amaçlayanlar, yemeğe önem verenler ve yöreselci turistler olmak üzere beş gastronomi turisti tipolojisi belirlemişlerdir. Charters ve Ali Knight (2002) ise şarap turistlerinin tutum ve davranışlarını incelemişler ve sonuç olarak "şarap severler, şarap konusunda oldukça bilgili olanlar, şarap konusunda resmi olmayarak eğitimli ve şarap deneyiminde bilgili olanlar ve acemi şarap turistleri" olmak üzere dört kısma ayırmışlardır. Söz konusu çalışmalar ele alındığında genel olarak gastronomi turistlerinin demografik özelliklerine ve seyahat motivasyonlarına odaklanıldığı fakat bu turistlerin görüş ve fikirlerinden yola çıkarak taksonomi gerçekleştirilmediği görülmektedir. Yapılan çalışmalarda nicel yöntemler aracılığıyla veri toplanmasına ağırlık verilmesi turistlerin subjektif bakış açılarının göz ardı edilmesine neden olmaktadır.

\section{ARAŞTIRMANIN AMACI ve ÖNEMI}

TÜRSAB'ın 2004-2014 yılları arası turizm verilerini incelediği gastronomi turizmi raporuna göre 2004 yılında Türkiye'nin turizm geliri toplamı 17 milyar dolar seviyesindeyken turistlerin yeme ve içme için yaptığı harcamanın 3,1 milyar dolar olduğu ancak 2014 yılına varıldığında bu rakamın iki katından daha yüksek bir düzeye eriştiği belirtilmiştir. 2014 yılında Türkiye'yi ziyaret eden 41 milyon 415 bin turistin yaptığ 34,3 milyar dolarlık toplam harcamanın 6 milyar 523 milyon dolarını yeme ve içmeye ayırdığı görülmektedir. Toplam harcamalar içinde \%19'luk paya karşıllk gelen bu rakam, turistlerin destinasyon seçiminde yeme içmenin de önemli bir unsur olduğunu göstermektedir (TÜRSAB, 2015). Gastronomi Turizmi Derneği ve Xsights Araştırma'nın ortak yürüttüğü çalışma sonuçları (2017) ise gastronomi turistlerinin harcadıkları 945 doların 245 dolarını yeme içmeye ayırdıklarını, diğer turistlerin 837 doların 171 dolarını yeme içmeye ayırdığını ortaya koymaktadır. Gastronomi turizminin yükselen eğimi araştırmacıların bu alandaki çalışmalarını arttırmaktadır. Bununla birlikte gastronomi turistlerinin tipolojilerinin belirlendiği sınırlı sayıda araştırmaya rastlanmaktadır (Şimşek ve Selçuk, 2018). Söz konusu araştırmalarda gastronomi turistlerinin demografik özelliklerine ağırlık verildiği bununla birlikte gastronomi turistlerinin görüşlerinden yola çıkılarak bir taksonominin geliştirilmediği gözlemlenmektedir. Buradan hareketle bu çalışmada gastronomi turistlerine yönelik bir taksonomi geliştirilmesi hedeflenmekte ve bu amaçla $Q$ metodundan yararlanılmaktadır. Uluslararası literatürde yaygınlıkla kullanılan $\mathrm{Q}$ metodu turistlerin sinıflandırılmasında kullanılmış (Tan vd., 2014) ancak ulusal literatürde turizm alanında metodun kullanımına 
rastlanmamıştır. Bu çalışmada UNESCO (2015) tarafından "Yaratıcı Şehirler Ağı" listesinde 'Gastronomi Şehri' olarak ilan edilen Gaziantep'i ziyaret eden gastronomi turistlerinin Q metodu aracılığıyla taksonomisinin geliştirilmesi amaçlanmaktadır. Elde edilen bulgular gastronomi değerleri ile ön plana çıkmak isteyen destinasyonlara gastronomi turistlerinin özellikleri hakkında bilgi vermesi açısından önem taşımaktadır.

\section{ARAŞTIRMA YÖNTEMI}

Öncelikle psikiyatri alanında kullanılmaya başlanan Q metot Alman bilim adamı William Stephenson tarafından 1930'lu yıllarda geliştirilmiştir. Sosyal bilimler alanında Brown tarafından kullanılmaya başlanan metot nicel ve nitel metodolojinin birlikte kullanıldığı bir araştırma tekniği olarak değerlendirilmektedir (Koçak, 2010). Sosyal bilimlerde sıklıkla kullanılan $\mathrm{R}$ metoduna kıyasla $Q$ metodunda sunulan cümlelere ek olarak katılımcıların kendi düşüncelerini ifade edebilme olanağı sunulmaktadır. $Q$ metodunda $R$ metodun aksine katılımciya verilen ifadelerin değil aynı düşünceye sahip kişilerin gruplanması esas olarak alınmaktadır (Demir ve Kul, 2011). Bu çalışmada $Q$ metot kapsamında araştırma tasarımı olarak yapısal tasarım benimsenerek literatür incelemesi sonucunda $Q$ ifadeler oluşturulmuştur. Araştırmada amaçlı örneklem seçiminden yararlanılmıştır. Hedeflenen grubun ortak fikirlerini yansıttığı düşünülen grup temsilcileri olarak Gaziantep Mutfak Sanatları Merkezi'ni ziyaret eden 18 yaş üstü turistler örneklem olarak belirlenmiştir. $Q$ dizgisi oluşturma sürecinde bireysel düşüncelerin ve değerlendirmelerin daha çok ön plana çıktığı zoraki dağılım seçeneği kullanılmıştır (Şekil 1).

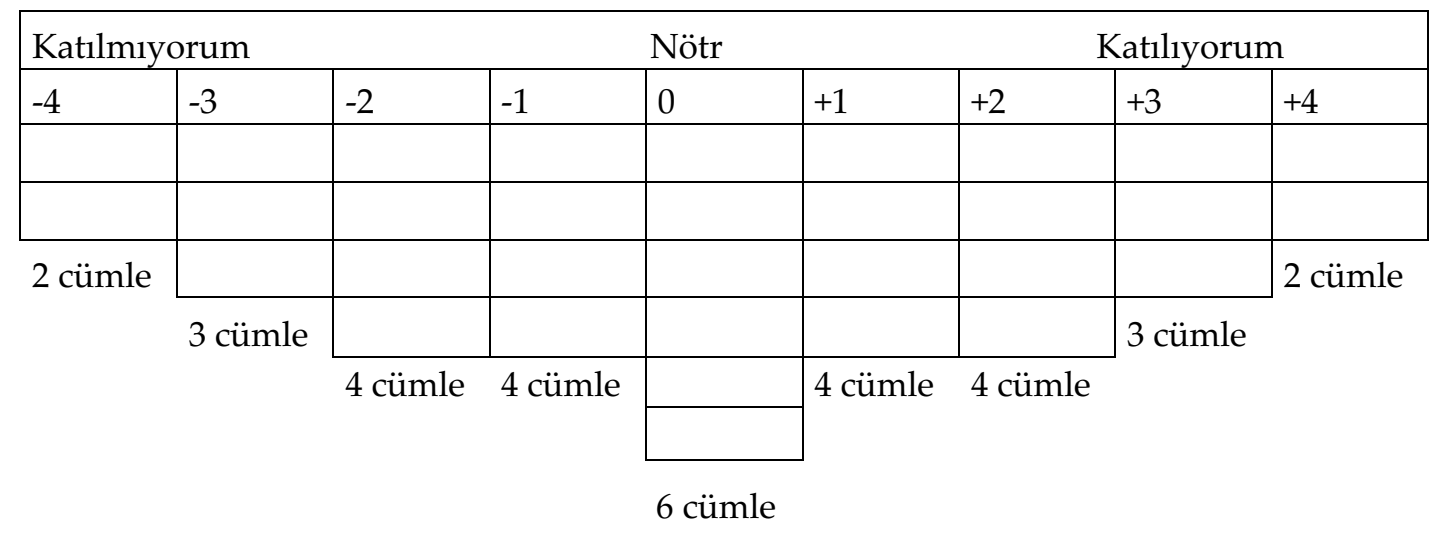

Şekil 1. Gastronomi Turizmi Turist Taksonomisi Q Dizgisi

Zoraki dağılım kapsamında oluşturulan $Q$ dizgisi ifadelerinin belirlenmesinde gastronomi alanında yapılan çalışmalar ele alınmıştır (Hsu ve Huang, 2007; Kesici, 2012; Bekar ve Kılıç, 2014; Belpınar, 2014; Guzman vd., 2014; Kraftchich vd., 2014; Üner, 2014; Birdir ve Akgöl, 2015; Akbaba ve Kargiglioğlu, 2016; Sorokina, 2016; Akkuş, 2017; Chang ve Mak, 2018; Şimşek ve Selçuk, 2018; Üzümcü, 2018; Yeşilyurt ve Arıca, 2018). Öncelikle beş ana başlık altında 27 alt başlık oluşturulmuş ve her alt başlık için biri olumlu biri olumsuz olmak üzere ikişer cümle yazılarak ifade havuzunda toplam 54 ifade elde edilmiştir. Bu ifadelerden 22 adeti birbirini tekrarlama, aynı anlamı çağrıştırma nedenleri ile elenerek beş ana başlık, 16 alt başlık ve olumlu ve olumsuz ifadeler olmak üzere 32 cümleden oluşan $Q$ dizgisi hazırlanmıştır. $Q$ dizgisi ifadelerine rastgele numaralar verilerek katılımcılar tarafından birbirinin devamı olarak algılanmasının önüne geçilmiştir. Q dizgisi kapsamında oluşturulan beş ana başlık ve alt boyutları;

- Yiyecek (yemeğin lezzeti, yemeğin görünümü) 
- Restoran (fiziksel özellikler, personel, menüye ilişkin özellikler)

- Motivasyon (kaçış, sosyalleşme, deneyim, eğitim, kültür)

- Kişilik özellikleri (neofobi, neofili)

- Destinasyonun gastronomik imajı (ayırt edicilik, çekicilik, sağlık ve güvenlik, uygunluk ve fiyat) şeklindedir.

Q dizgisi ifadelerinin belirlenmesinden sonra katılımciların cümlelerini neye göre derecelendirdiğini ve eksik bulunan ifadelerin olup olmadığını öğrenmek amacıyla görüşme kağıtlarına;

1. Cümlelerinizi neden $+4^{\prime}$ e yerleştirdiniz?

2. Cümlelerinizi neden -4'e yerleştirdiniz?

3. Konu ile ilgili önemli olduğunu düşündügünüz ancak araştırmada yer verilmeyen bir konu var $\mathrm{m}$ ?

4. Sunulan cümleler içerisinde sizi inciten/rahatsız eden bir ifadeye rastladınız mı? şeklinde sorular yöneltilmiştir.

Araştırmaya başlamadan önce $Q$ dizgisinde yer alan ifadelerin anlaşılırlığını test etmek amacıyla 8 kişiye pilot test uygulanmıştır. Araştırma kapsamında elde edilen veri setinin analizinde ücretsiz yazılım sunan PQMethod 2.35 (Schmolck, 2014) programından yararlanılmıştır.

\section{ARAŞTIRMA BULGULARI}

Ağustos - Eylül 2019 tarihleri arasında gerçekleştirilen araştırma sonunda 38 katılımcıdan veri elde edilmiştir. Kadın katılımcılar ' $K$ ', erkek katılımcılar ' $E$ ' ile temsil edilmiştir. Tablo 1'de yer alan katılımcıların demografik özellikleri incelendiğinde 20 adet kadın, 18 adet erkek katılımcının olduğu ve bu katılımcıların yaş ortalamasının 31 olduğu görülmektedir. Gastronomi turizmi kapsamında Gaziantep Mutfak Sanatları Merkezi'ni ziyaret eden ve çalışmaya katılan turistlerin daha çok genç yaş grubunda oldukları söylenebilir. Katılımcı sayısına göre İstanbul ilk sırada yer almakta ancak bölgelere göre incelendiğinde Gaziantep Mutfak Sanatları Merkezi'nin en fazla Akdeniz Bölgesi'ndeki farklı illerden ziyaret edildiği görülmektedir.

Araştırmanın bir sonraki aşamasında temel bileşen analizi ve varimax rotasyon aracilığıyla faktör yük değerleri hesaplanmıştır. Faktörlerdeki anlamlılık değerinin belirlenmesi amacıyla $(1 / \sqrt{ }$ n).2,58 anlamlılık formülü uygulanmıştır (Demir ve Kul, 2011: 85). Formülde yer alan " $n$ " değeri çalışmada kullanılan ifade sayısını temsil etmektedir. Bu çalışmada 32 ifade yer almakta ve buna göre bu çalışma için anlamlılık değeri 0.4577 olarak ortaya çıkmaktadır. Buradan hareketle faktör yükü 0.45 ve üzeri değere sahip olan katılımcllar araştırmaya dahil edilmiş, bu değerin altında kalan ya da birden fazla grupta anlamlı değer sonucuna ulaşılan katılımcılar analize dahil edilmemiştir (K10 ve E17) (Tablo 2). Buna göre tabloda 36 katılımcının dört faktör altında toplandığı görülmektedir. Her bir katılımcının hangi faktör altında anlamlı olarak yer aldığının görülebilmesi için katılımcının yer aldığı faktörün değeri koyu ile belirtilmiş ve aynı zamanda ' $X$ ' işareti program tarafından otomatik olarak atanmıştır. Tablo 2'ye göre birinci faktör altında 9, ikinci faktör altında 13, üçüncü faktör altında 5 ve dördüncü faktör altında 9 katılımcının toplandığı görülmektedir. 
Tablo 1. Katılımcıların Demografik Profili

\begin{tabular}{|c|c|c|c|}
\hline Sira No. & Katılımcılar & Yaş & Şehir \\
\hline 1 & K1 & 27 & Kahramanmaraş \\
\hline 2 & K2 & 50 & Almanya \\
\hline 3 & E1 & 32 & İstanbul \\
\hline 4 & K3 & 22 & Adana \\
\hline 5 & E2 & 30 & İstanbul \\
\hline 6 & E3 & 40 & Balıkesir \\
\hline 7 & $\mathrm{E} 4$ & 38 & Manisa \\
\hline 8 & E5 & 29 & Şanlıurfa \\
\hline 9 & E6 & 32 & KKTC \\
\hline 10 & K4 & 31 & KKTC \\
\hline 11 & K5 & 30 & İzmir \\
\hline 12 & K6 & 19 & Kahramanmaraş \\
\hline 13 & K7 & 33 & Ankara \\
\hline 14 & E7 & 27 & İzmir \\
\hline 15 & K8 & 25 & Çorum \\
\hline 16 & K9 & 27 & Malatya \\
\hline 17 & K10 & 22 & İstanbul \\
\hline 18 & E8 & 29 & İstanbul \\
\hline 19 & E9 & 32 & Mersin \\
\hline 20 & E10 & 28 & İstanbul \\
\hline 21 & K11 & 26 & Hatay \\
\hline 22 & K12 & 26 & Sivas \\
\hline 23 & E11 & 27 & Diyarbakır \\
\hline 24 & K13 & 28 & Mersin \\
\hline 25 & E12 & 34 & Adana \\
\hline 26 & K14 & 37 & KKTC \\
\hline 27 & E13 & 42 & Şanlıurfa \\
\hline 28 & K15 & 49 & Diyarbakır \\
\hline 29 & E14 & 24 & Balıkesir \\
\hline 30 & E15 & 22 & Mardin \\
\hline 31 & E16 & 27 & Adana \\
\hline 32 & E17 & 34 & Çorum \\
\hline 33 & E18 & 29 & Giresun \\
\hline 34 & K16 & 29 & Adana \\
\hline 35 & K17 & 31 & Adana \\
\hline 36 & K18 & 49 & İstanbul \\
\hline 37 & K19 & 34 & Ankara \\
\hline 38 & K20 & 28 & Elazı̆̆ \\
\hline
\end{tabular}

Tablo 3'te araştırmada yer alan ifadelerin $\mathrm{Z}$ değerleri ve her bir gruptaki önem sırası yer almaktadır. Buna göre birinci faktör altında toplanan turistler için ilk sırada "Gaziantep'in kendisini diğer yörelerden ayıran eşsiz yiyecek içecekleri vardır. (31)" ifadesi yer almaktadır. Söz konusu turistler için yiyeceklerin ayırt edici imajının önemli olduğunu söylemek mümkündür. Bu grupta yer alan turistler için en az önemli olan ifade "Restoranda fiziksel koşullarla ilgilenmez yalnızca yediğim yemeğe dikkat ederim. (4)" olmuştur. Bu turist grubu için Gaziantep'i diğer 
bölgelerden farklı kılan kendine özgü lezzetlerin olması en önemli etken olarak görülürken restoranın fiziksel koşullarının daha az etkili olduğu görülmektedir.

Tablo 2. Faktör Yükleri

\begin{tabular}{|c|c|c|c|c|}
\hline Katılımcı & 1 & 2 & 3 & 4 \\
\hline K1 & 0.3217 & $0.7594 X$ & -0.0378 & 0.3372 \\
\hline $\mathrm{K} 2$ & 0.4863 & 0.1525 & $0.5060 X$ & 0.3358 \\
\hline E1 & $0.6128 X$ & 0.4681 & 0.1313 & 0.1123 \\
\hline K3 & 0.2647 & $0.7175 X$ & 0.2433 & 0.2356 \\
\hline E2 & 0.2325 & $0.7661 X$ & 0.1798 & 0.3984 \\
\hline E3 & 0.3390 & 0.2736 & 0.4155 & $0.5988 X$ \\
\hline $\mathrm{E} 4$ & -0.1258 & $0.6417 X$ & 0.5349 & 0.2741 \\
\hline E5 & 0.4615 & 0.1462 & $0.7065 X$ & 0.1487 \\
\hline E6 & 0.2224 & $0.7218 X$ & 0.3031 & 0.3386 \\
\hline K4 & 0.2873 & $0.5893 X$ & 0.5042 & 0.3667 \\
\hline K5 & $0.6411 X$ & 0.4988 & 0.2711 & 0.3310 \\
\hline K6 & 0.4182 & 0.3932 & $0.5505 X$ & 0.2047 \\
\hline K7 & 0.4660 & $0.6473 X$ & 0.2885 & 0.2080 \\
\hline E7 & 0.2272 & 0.3141 & 0.2311 & $0.8437 \mathrm{X}$ \\
\hline K8 & 0.1955 & 0.4064 & 0.1953 & $0.8014 X$ \\
\hline K9 & 0.2213 & $0.6197 X$ & 0.2502 & 0.1080 \\
\hline K10 & 0.4475 & 0.4108 & 0.2855 & 0.4254 \\
\hline E8 & 0.2060 & $0.5850 \mathrm{X}$ & 0.3466 & 0.3490 \\
\hline E9 & 0.4629 & 0.2077 & 0.3871 & $0.6536 \mathrm{X}$ \\
\hline E10 & 0.5231 & 0.3143 & 0.3072 & $0.5588 X$ \\
\hline K11 & 0.5881 & 0.2063 & 0.3637 & $0.6111 X$ \\
\hline K12 & $0.5705 X$ & 0.3068 & 0.1834 & 0.5372 \\
\hline E11 & $0.6474 X$ & 0.2244 & 0.2103 & 0.4331 \\
\hline K13 & $0.6280 X$ & 0.4207 & 0.2353 & 0.1677 \\
\hline E12 & 0.4996 & $0.6081 X$ & 0.1394 & 0.3430 \\
\hline K14 & 0.3765 & $0.5949 X$ & 0.3584 & 0.2765 \\
\hline E13 & 0.1398 & 0.2092 & $0.7701 X$ & 0.3032 \\
\hline K15 & 0.4239 & $0.5526 X$ & 0.3274 & 0.4176 \\
\hline E14 & 0.4274 & $0.7048 X$ & 0.1434 & 0.2701 \\
\hline K16 & 0.1370 & 0.2612 & $0.7214 X$ & 0.1715 \\
\hline E15 & $0.5849 X$ & 0.3252 & 0.4153 & 0.2894 \\
\hline E16 & $0.6010 X$ & 0.4650 & 0.1587 & 0.3641 \\
\hline K17 & $0.6560 X$ & 0.2406 & 0.1758 & 0.5102 \\
\hline K18 & 0.3773 & 0.4909 & 0.2706 & $0.5513 X$ \\
\hline E17 & 0.5447 & 0.2848 & 0.5354 & 0.2377 \\
\hline E18 & $0.5583 X$ & 0.2217 & 0.1761 & 0.3755 \\
\hline K19 & 0.3451 & 0.3548 & 0.1268 & $0.6676 \mathrm{X}$ \\
\hline K20 & 0.2331 & 0.3101 & 0.2632 & $0.7487 \mathrm{X}$ \\
\hline
\end{tabular}

Görüşleri ikinci faktör altında toplanan turistler için “Gaziantep'teki yiyecek içecekler beni buraya çekiyor. (27)" ifadesi birinci sırada yer almaktadır. "Gastronomi turizmi yerel kültürü anlamak için eşsiz bir fırsattır. (18)" ve "Gittiğim destinasyondaki yediğim yemeğin lezzeti önemlidir. (32)" ifadeleri sırasıyla ikinci ve üçüncü öneme sahip ifadeler olarak belirlenmiştir. Bu 
gruptaki turistlerin, “Gaziantep lezzetlerinin sağlık açısından güvenli olmadığını düşünüyorum. (17)" cümlesine kesinlikle katılmadıklarını belirttikleri için Gaziantep'teki lezzetler ile ilgili olarak sağlık ve güvenlik açısından bir risk görmedikleri söylenebilir. Bu faktör altındaki turistlere göre bir destinasyonun gastronomik çekiciliğinin yüksek olması, motivasyon unsuru olarak kültürün zenginliği ve yenilen yemeğin lezzeti en yüksek düzeyde önem taşıyan boyutlar olmuştur.

Üçüncü faktörde yer alan turistlere ilişkin bulgular incelendiğinde ilk sırada "Gittiğim destinasyondaki yediğim yemeğin lezzeti önemlidir. (32)"; ikinci sırada "Yediğim yemeğin görünüş olarak iştah açıcı olması önemlidir. (21)" ve üçüncü sırada "Gaziantep'teki yiyecek içecekleri sağlık açısından güvenle tüketebilirim. (23)" cümleleri yer almıştır. Buradan hareketle bu grup için yemeğin lezzeti, görünümü ve sağlık boyutlarının daha yüksek değerde önem taşıdığ1 görülmektedir. Bu grubun en düşük derecede önem atfettiği “Gaziantep lezzetlerinin sağlık açısından güvenli olmadığını düşünüyorum. (17)" ifade, başka bir deyişle gastronomik imaj boyutu altında yer alan olumsuz cümle olması ise yiyecek ve içeceklerin sağlıklı olup olmadığına dikkat ettiklerini destekler niteliktedir.

Dördüncü faktörde, en olumlu yaklaşılan ifade "Gastronomi turizmi yerel kültürü anlamak için eşsiz bir fırsattır. (18)", en olumsuz yaklaşılan ise "Yerel halkın kültürünün yiyecek içecekle bir ilgisi yoktur. (16)" olmuştur. Bu görüş altında toplanan bireylerin, yerel kültürün gastronomi turizmi vasitasıyla öğrenebilmenin mümkün olduğunu ve yerel halkın kültürünün bölgedeki yiyecek içecek kültürüyle bağlantısının olduğunu düşündükleri görülmektedir. 18 numaralı olumlu ifadenin karşıtı olan 16 numaralı ifadeye düşük değer vermeleri de bu yargıyı desteklemektedir. Ayrıca ilk sıradaki cümlenin kültür boyutu altında yer almasından dolayı bu turistler için bir destinasyonu ziyaret etmede kültürün önemli bir motivasyon unsuru olduğu söylenebilmektedir.

Tablo 3. Maddelere İlişkin Z Değerleri ve Maddelerin Önem Sırası

\begin{tabular}{|l|c|c|c|c|c|c|c|c|}
\hline \multirow{2}{*}{ Faktör/Madde } & \multicolumn{2}{|c|}{ Faktör 1 } & \multicolumn{2}{|c|}{ Faktör 2 } & \multicolumn{2}{|c|}{ Faktör 3 } & \multicolumn{2}{c|}{ Faktör 4 } \\
\cline { 2 - 9 } & $\mathrm{Z}$ & $\mathrm{S}$ & $\mathrm{Z}$ & $\mathrm{S}$ & $\mathrm{Z}$ & $\mathrm{S}$ & $\mathrm{Z}$ & $\mathrm{S}$ \\
\hline $\begin{array}{l}\text { Gaziantep'in kendisini diğer yörelerden ayıran } \\
\text { eşsiz yiyecek içecekleri vardır. (31) }\end{array}$ & 1.69 & 1 & 1.31 & 4 & 1.29 & 4 & 1.23 & 6 \\
\hline $\begin{array}{l}\text { Gastronomi turizmi yerel kültürü anlamak için } \\
\text { eşsiz bir fırsattır. (18) }\end{array}$ & 1.45 & 2 & 1.47 & 2 & 1.06 & 7 & 1.60 & 1 \\
\hline $\begin{array}{l}\text { Yediğgim yemeğin görünüş olarak iştah açıc1 } \\
\text { olması önemlidir. (21) }\end{array}$ & 1.41 & 3 & 1.03 & 7 & 1.64 & 2 & 1.31 & 4 \\
\hline $\begin{array}{l}\text { Gittiğim destinasyondaki yediğim yemeğin } \\
\text { lezzeti önemlidir. (32) }\end{array}$ & 1.28 & 4 & 1.33 & 3 & 1.66 & 1 & 1.25 & 5 \\
\hline $\begin{array}{l}\text { Gaziantep'teki yiyecek içecekler beni buraya } \\
\text { çekiyor. (27) }\end{array}$ & 1.17 & 5 & 1.58 & 1 & -0.51 & 22 & 1.08 & 7 \\
\hline $\begin{array}{l}\text { Restoran çalışanlarının menüdeki yiyecek- } \\
\text { içecekle ilgili tavsiyelerde bulunması } \\
\text { önemlidir. (25) }\end{array}$ & 1.04 & 6 & 1.02 & 8 & 0.99 & 8 & 0.58 & 12 \\
\hline $\begin{array}{l}\text { Yöresel yiyecek-içecekleri yerinde tatmak } \\
\text { insana otantik bir hava verir. (20) }\end{array}$ & 0.92 & 7 & 1.26 & 5 & 0.48 & 11 & 1.36 & 2 \\
\hline $\begin{array}{l}\text { Farklı yöresel yiyecek-içecek deneyimleri ailem } \\
\text { ve arkadaşlarımla bir arada olmak için bir } \\
\text { fırsattır. (12) }\end{array}$ & 0.91 & 8 & 0.14 & 14 & 0.23 & 14 & 0.69 & 10 \\
\hline $\begin{array}{l}\text { Restoranın fiziksel özellikleri (sıcaklık, koku, } \\
\text { müzik, dekorasyon, rahatlık) yediğim yemekle } \\
\text { uyumlu olmalıdır. (14) }\end{array}$ & 0.87 & 9 & 0.84 & 13 & 0.30 & 13 & 0.79 & 8 \\
\hline $\begin{array}{l}\text { Gittiğim destinasyonda öncelikli olarak yöresel } \\
\text { yiyecek ve içecekleri denerim. (9) }\end{array}$ & 0.79 & 10 & 0.89 & 10 & 0.79 & 9 & 0.77 & 9 \\
\hline
\end{tabular}




\begin{tabular}{|c|c|c|c|c|c|c|c|c|}
\hline $\begin{array}{l}\text { Yöresel yiyeceklerin nasıl pişirildiğini, } \\
\text { özelliklerini ve tarihini öğrenmek isterim. (3) }\end{array}$ & 0.74 & 11 & 0.87 & 11 & -0.23 & 18 & 0.49 & 14 \\
\hline $\begin{array}{l}\text { Gaziantep'teki yiyecek içecekleri sağlık } \\
\text { açısından güvenle tüketebilirim. (23) }\end{array}$ & 0.66 & 12 & 0.84 & 12 & 1.46 & 3 & 0.17 & 15 \\
\hline $\begin{array}{l}\text { Menüde yöresel yiyecek-içecekler ve bunlarla } \\
\text { ilgili tanıtıcı bilgiler ararım. (1) }\end{array}$ & 0.61 & 13 & 1.09 & 6 & -0.17 & 17 & 0.11 & 16 \\
\hline $\begin{array}{l}\text { Seyahatimde neler gördüğüm ne yediğimden } \\
\text { daha önemlidir. (24) }\end{array}$ & 0.16 & 14 & -0.46 & 18 & 0.79 & 10 & -0.29 & 19 \\
\hline $\begin{array}{l}\text { Gaziantep'e yalnızca yiyecek-içecekler için } \\
\text { gelmem. (13) }\end{array}$ & 0.11 & 15 & -0.93 & 25 & 1.27 & 5 & 0.60 & 11 \\
\hline Gaziantep'teki yiyecek içecekler pahalıdır. (2) & 0.05 & 16 & -1.20 & 30 & -1.32 & 30 & -0.00 & 17 \\
\hline $\begin{array}{l}\text { Restorandaki yöresel yiyecek-içecek deneyimi } \\
\text { bana günlük rutinimden uzaklaştı̆ı̆ımı } \\
\text { hissettirir. (8) }\end{array}$ & -0.15 & 17 & -0.05 & 15 & 0.35 & 12 & 1.34 & 3 \\
\hline $\begin{array}{l}\text { Yiyecek-içecek gibi benzer ilgi alanlarına sahip } \\
\text { bireylerle tanışmak ilgimi çekmez. (26) }\end{array}$ & -0.15 & 18 & -0.36 & 17 & 0.16 & 15 & -0.77 & 23 \\
\hline $\begin{array}{l}\text { Gittiğim destinasyonda yalnızca önceden } \\
\text { bildiğim yiyecek-içecekleri denerim. (29) }\end{array}$ & -0.30 & 19 & -0.79 & 22 & -0.85 & 26 & -1.58 & 31 \\
\hline $\begin{array}{l}\text { Gaziantep'te yiyecek içecek fiyatlarının uygun } \\
\text { olduğunu düşünüyorum. (10) }\end{array}$ & -0.45 & 20 & 0.90 & 9 & 1.08 & 6 & 0.52 & 13 \\
\hline $\begin{array}{l}\text { Seyahatim esnasında karnımı doyurmak } \\
\text { benim için yeterlidir (19) }\end{array}$ & -0.46 & 21 & -0.74 & 21 & -1.16 & 28 & -1.14 & 27 \\
\hline $\begin{array}{l}\text { Gaziantep lezzetlerinin sağlık açısından } \\
\text { güvenli olmadığını düşünüyorum. (17) }\end{array}$ & -0.66 & 22 & -1.52 & 32 & -1.85 & 32 & -0.28 & 18 \\
\hline $\begin{array}{l}\text { Her gün yediğim yemeklerden farklı bir şeyler } \\
\text { deneyimlemek beni heyecanlandırmaz. (7) }\end{array}$ & -0.74 & 23 & -0.99 & 27 & -0.45 & 20 & -1.36 & 28 \\
\hline $\begin{array}{l}\text { Yöresel yiyecek-içecekler bana günlük } \\
\text { rutinimden farklı bir deneyim sunmaz. (15) }\end{array}$ & -0.77 & 24 & -0.60 & 19 & -0.49 & 21 & -1.40 & 29 \\
\hline $\begin{array}{l}\text { Restoran çalışanlarının yalnızca yiyecek- } \\
\text { içeceği servis etmesi yeterlidir. (28) }\end{array}$ & -0.83 & 25 & -1.02 & 28 & -0.08 & 16 & -0.50 & 21 \\
\hline $\begin{array}{l}\text { Gittiğim destinasyondaki yöresel yiyecek } \\
\text { içecekleri araştırmak zaman kaybidır. (5) }\end{array}$ & -1.13 & 26 & -1.38 & 31 & -0.79 & 25 & -0.81 & 24 \\
\hline $\begin{array}{l}\text { Menüde yöresel yiyecek-içecek anlamında } \\
\text { çeşitlilik önemli değildir. (22) }\end{array}$ & -1.18 & 27 & -0.69 & 20 & -0.37 & 19 & -0.88 & 26 \\
\hline $\begin{array}{l}\text { Yiyecekle ilgili müzeler, sanat galerileri, } \\
\text { tiyatrolar gibi eğitici aktivitelere gitmek ilgimi } \\
\text { çekmez. (30) }\end{array}$ & -1.19 & 28 & -0.81 & 24 & -0.64 & 23 & -0.51 & 22 \\
\hline Yemeğin görünümüne önem vermem. (11) & -1.37 & 29 & -0.97 & 26 & -1.25 & 29 & -1.45 & 30 \\
\hline $\begin{array}{l}\text { Gaziantep'teki yiyecek içeceklerin yakın } \\
\text { bölgelerdeki diğer destinasyonlardan farkı } \\
\text { yoktur. (6) }\end{array}$ & -1.39 & 30 & -0.81 & 23 & -1.65 & 31 & -0.47 & 20 \\
\hline $\begin{array}{l}\text { Yerel halkın kültürünün yiyecek içecekle bir } \\
\text { ilgisi yoktur. (16) }\end{array}$ & -1.54 & 31 & -1.02 & 29 & -1.01 & 27 & -1.63 & 32 \\
\hline $\begin{array}{l}\text { Restoranda fiziksel koşullarla ilgilenmez } \\
\text { yalnızca yediğim yemeğe dikkat ederim. (4) }\end{array}$ & -1.58 & 32 & -0.25 & 16 & -0.74 & 24 & -0.81 & 25 \\
\hline
\end{tabular}

Tablo 4'te, belirlenen dört faktörün özellikleri gösterilmektedir. Araştırmada belirlenen faktörlere ait güvenilirliğin ölçülmesinde birleşik güvenilirlikten yararlanılmıştır. Birleşik güvenilirlik değerinin 0.60 ve üzeri değerde olması ölçekte birleşik güvenilirliğe erişildiğine işaret etmektedir (Ustasüleyman ve Eyüboğlu, 2010; Prebensen vd., 2014). Bu araştırmada 0.90 ve üzeri faktörlerin güvenilir olduğu sonucuna varılmıştır.

Tablo 5, 6, 7 ve 8 faktörler arasındaki ayırt edici maddeleri göstermektedir. Tablolarda verilen maddeler, ilgili faktör altında toplanan turist gruplarının diğer gruplardan hangi konularda farklı düşündüğünü açıklamaktadır. Tablo 5 incelendiğinde, bu gruptaki turistlerin diğerlerinden farklı olarak gittikleri destinasyonda daha önceden bildikleri yiyecek-içecekleri 
deneme eğiliminde oldukları görülmektedir. Bir diğer deyişle bu turist grubu yenilikler karşısında nötr davranmaktadır. Dolayısıyla bu turist grubuna aşina olmadığı ve farklı lezzetlerin sunulmaması gerekmektedir. Bu gruptaki turistler, Gaziantep'teki yiyecek-içecek fiyatlarının pahalı olduğunu düşünmektedir. Bir diğer bulguya göre, bu turistler için yemeğin lezzeti, görünümü kadar önemli olan bir konu da restoranın fiziksel koşulları olmaktadır. En olumsuz yaklaşılan 4 numaralı cümle ile ilgili elde edilen nitel verilerde katılımcı K5'e neden -4 için bu cümleyi uygun gördüğü sorulduğunda şu şekilde ifade etmiştir:

Tablo 4. Faktörlerin Özellikleri

\begin{tabular}{|l|c|c|c|c|}
\hline & Faktör 1 & Faktör 2 & Faktör 3 & Faktör 4 \\
\hline Tanımlanan Değerlerin Sayısı & 9 & 13 & 5 & 9 \\
\hline Ortalama Güvenilirlik Katsayısı & 0.800 & 0.800 & 0.800 & 0.800 \\
\hline Birleșik Güvenilirlik & 0.973 & 0.981 & 0.952 & 0.973 \\
\hline Faktörlerin Z Skorlarının Standart Hatası & 0.164 & 0.137 & 0.218 & 0.164 \\
\hline
\end{tabular}

"Gittiğim restoranda sadece yemeğe odaklanmak bana hitap eden bir yaklaşım olmadığı için -4 değeri vermek istedim. Çünkü benim için yediğim yemek kadar ortamın atmosferi de bir o kadar önemli. Yemek ne kadar lezzetli olursa olsun fiziksel koşulları kötü olan bir restoranda bulunmak beni kesinlikle olumsuz etkiler." (K5)

Tablo 5. Faktör 1'in Ayırt Edici İfadeleri

\begin{tabular}{|c|c|c|c|c|c|c|c|c|}
\hline \multirow[b]{2}{*}{ Terimler } & \multicolumn{2}{|c|}{ Faktör 1} & \multicolumn{2}{|c|}{ Faktör 2} & \multicolumn{2}{|c|}{ Faktör 3} & \multicolumn{2}{|c|}{ Faktör 4} \\
\hline & $\begin{array}{l}\text { Q- } \\
\text { SV }\end{array}$ & $\begin{array}{l}\text { Z- } \\
\text { SCR }\end{array}$ & $\begin{array}{l}\text { Q- } \\
\text { SV }\end{array}$ & $\begin{array}{l}\text { Z- } \\
\text { SCR }\end{array}$ & $\begin{array}{l}\text { Q- } \\
\text { SV }\end{array}$ & $\begin{array}{l}\text { Z- } \\
\text { SCR }\end{array}$ & $\begin{array}{l}\text { Q- } \\
\text { SV }\end{array}$ & $\begin{array}{l}\text { Z- } \\
\text { SCR }\end{array}$ \\
\hline $\begin{array}{l}\text { Gittiğgim destinasyonda yalnızca önceden } \\
\text { bildiğim yiyecek-içecekleri denerim. (29) }\end{array}$ & 0 & -0.30 & -1 & -0.79 & -2 & -0.85 & -4 & -1.58 \\
\hline $\begin{array}{l}\text { Gaziantep'te yiyecek içecek fiyatlarının } \\
\text { uygun olduğunu düşünüyorum. (10) }\end{array}$ & -1 & $-0.45^{*}$ & 2 & 0.90 & 2 & 1.08 & 1 & 0.52 \\
\hline $\begin{array}{l}\text { Restoranda fiziksel koşullarla ilgilenmez } \\
\text { yalnızca yediğim yemeğe dikkat ederim. } \\
\text { (4) }\end{array}$ & -4 & $-1.58^{*}$ & 0 & -0.25 & -2 & -0.74 & -2 & -0.81 \\
\hline
\end{tabular}

Q-SV (Q-Sort Value) ve Z-SCR (Z-Score) değerleri gösterilmektedir.

$\left(P<.05 ;\left(^{*}\right)\right.$ ile gösterilenlerde anlamlilık $\left.P<.01\right)$

Tablo 6'ya göre, menüde yöresel yiyecek-içecekler ve bunlarla ilgili tanıtıcı bilgiler arama (1) ile ilgili ifadenin, faktör 2'de diğerlerine oranla yüksek değerde ayırt edici bir ifade olduğu görülmektedir. “Gaziantep'e yalnızca yiyecek-içecekler için gelmem. (13)" ifadesi diğer faktörlerde nötr ve olumlu iken faktör 2' de negatif değer alıp bu faktörü farklılaştıran bir diğer maddedir. Buna göre bu grupta yer alanların ağırlıklı olarak Gaziantep'teki yiyecek-içecekleri deneyimlemek için geldiğini söylemek mümkündür. Bu grupta yer alan turistler için menüde yiyecek-içeceklere ait tanıtıcı bilgilerin olması önem taşımaktadır. Bu faktörü diğerlerinden 
farklılaştıran K1 kodlu katılımcının +4 ve -4 'e yerleştirdiği ifadelere ilişkin görüşleri aşağıdaki gibidir:

"Madde 17 ve 5'e -4 değeri verdim çünkü Gaziantep yemeklerinin sağlık açısından güvenli olmadığı fikrine katılmıyorum. Aksine sağlıkl ve yararlı birçok yemeği var. Diğer faktöre gelecek olursak gittiğim destinasyonda yöresel lezzetleri araştırmanın zaman kaybı değil o mutfağın kültürü hakkında bilgi sahibi olma konusunda olumlu etkileri olduğuna inanıyorum. +4 değgerini verdiğim ifadeler ise Gaziantep'e gelme nedenimizi ortaya çıkarıyor. Gaziantep denilince akla gelen ilk etken gastronomi olduğu için 'Gaziantep'e ait lezzetler bizi buraya çekiyor (27)."

Tablo 6. Faktör 2'nin Ayırt Edici İfadeleri

\begin{tabular}{|l|l|l|l|l|l|l|l|l|l|}
\hline \multirow{2}{*}{ Terimler } & \multicolumn{2}{l|}{ Faktör 1 } & \multicolumn{2}{l|}{ Faktör 2 } & \multicolumn{2}{l|}{ Faktör 3 } & \multicolumn{2}{l|}{ Faktör 4 } \\
\cline { 2 - 10 } & $\begin{array}{l}\text { Q- } \\
\text { SV }\end{array}$ & $\begin{array}{l}\text { Z- } \\
\text { SCR }\end{array}$ & $\begin{array}{l}\text { Q- } \\
\text { SV }\end{array}$ & $\begin{array}{l}\text { Z- } \\
\text { SCR }\end{array}$ & $\begin{array}{l}\text { Q- } \\
\text { SV }\end{array}$ & $\begin{array}{l}\text { Z- } \\
\text { SCR }\end{array}$ & $\begin{array}{l}\text { Q- } \\
\text { SV }\end{array}$ & $\begin{array}{l}\text { Z- } \\
\text { SCR }\end{array}$ \\
\hline $\begin{array}{l}\text { Menüde yöresel yiyecek-içecekler ve } \\
\text { bunlarla ilgili tanıtıc bilgiler ararım. (1) }\end{array}$ & 1 & 0.61 & $\mathbf{2}$ & $\mathbf{1 . 0 9}$ & 0 & -0.17 & 0 & 0.11 \\
\hline $\begin{array}{l}\text { Gaziantep'e yalnızca yiyecek-içecekler } \\
\text { için gelmem. (13) }\end{array}$ & 0 & 0.11 & $\mathbf{- 2}$ & $\mathbf{- 0 . 9 3 ^ { * }}$ & 3 & 1.27 & 1 & 0.60 \\
\hline
\end{tabular}

Q-SV (Q-Sort Value) ve Z-SCR (Z-Score) değerleri gösterilmektedir.

$\left(P<.05 ;{ }^{*}\right)$ ile gösterilenlerde anlamlılı $\left.P<.01\right)$

Tablo 7'ye göre üçüncü faktörde turistlerin, Gaziantep'teki yiyecek ve içecekleri sağllk açısından daha güvenli bulduğu (23), Gaziantep'e yalnızca yiyecek-içecekler için gelmediği (13) ve seyahatlerinde yiyecek-içecekten ziyade diğer turistik unsurlara daha fazla önem verdiği açığa çıkmaktadır. Bu faktör altında birleşen turistlerin, diğerlerine nazaran yöresel yemeklerin nasıl pişirildiği ve tarihi hakkında bilgi sahibi olma (27) konusunda daha isteksiz olduğu anlaşılmaktadır. Ayrıca bu gruptaki turistlerin Gaziantep'e yalnızca gastronomi turizmi için gelmeyecekleri ve gelme sebepleri arasında gastronominin etkisinin düşük olduğu söylenebilir. Bu faktörü diğerlerinden farklılaştıran ifadelere göre katılımcıların cevapları incelendiğinde 13. ve 23. maddelere en yüksek değer (+4) atfeden K6 kodlu katılımciya nedeni sorulduğunda şu şekilde açıklamıştır:

"Gaziantep başarll bir gastronomi şehri ama bence sadece yiyecek ve içecekler için gelmek doğru olmaz. Bu yörenin kendine ait kültürel ve tarihi çekiciliklerini görmek için gelen de var, gelişmiş ve büyük bir şehir olduğu için gelen de. Ben de farklı bir amaçla geldim, gelince de yöresel yemeklerini deniyorum. Bu yemeklerin de sağlık açısından güvenli olduğunu düşünüyorum."

Tablo 8 'den yola çıarak, 4 . faktör altında yer alan turistlerin gastronomi turizmi kapsamında yöresel yiyecek-içecekler tatmalarını günlük rutinlerinden kaçış olarak gördüklerini söylemek mümkündür. Benzer şekilde, katılımcıların yöresel yiyecek-içeceklerin rutinden farklı bir deneyim sunmayacağı (15) ifadesine vermiş oldukları negatif değer de bunu desteklemektedir. $\mathrm{Bu}$ grupta yer alan turistler, gittikleri destinasyonda önceden bildikleri lezzetleri tercih etme hakkındaki ifadeye de en olumsuz yaklaşan bireyler olduğu için yeniliklere açık oldukları ve farklı tatlar denemekten kaçınmayacakları sonucuna ulaşılmaktadır. “Gittiğim destinasyonda 
yalnızca önceden bildiğim yiyecek-içecekleri denerim. (29)" ifadesine -4 değeri veren katılımcılardan bazılarının açıklamaları şu şekildedir:

Tablo 7: Faktör 3'ün Ayırt Edici İfadeleri

\begin{tabular}{|l|l|l|l|l|l|l|l|l|l|}
\hline & \multicolumn{2}{|l|}{ Faktör 1 } & \multicolumn{2}{l|}{ Faktör 2 } & \multicolumn{2}{l|}{ Faktör 3 } & \multicolumn{2}{l|}{ Faktör 4 } \\
\cline { 2 - 11 } Terimler & $\begin{array}{l}\text { Q- } \\
\text { SV }\end{array}$ & $\begin{array}{l}\text { Z- } \\
\text { SCR }\end{array}$ & $\begin{array}{l}\text { Q- } \\
\text { SV }\end{array}$ & $\begin{array}{l}\text { Z- } \\
\text { SCR }\end{array}$ & $\begin{array}{l}\text { Q- } \\
\text { SV }\end{array}$ & $\begin{array}{l}\text { Z- } \\
\text { SCR }\end{array}$ & $\begin{array}{l}\text { Q- } \\
\text { SV }\end{array}$ & $\begin{array}{l}\text { Z- } \\
\text { SCR }\end{array}$ \\
\hline $\begin{array}{l}\text { Gaziantep'teki yiyecek içecekleri sağlık } \\
\text { açısından güvenle tüketebilirim. (23) }\end{array}$ & 1 & 0.66 & 1 & 0.84 & $\mathbf{3}$ & $\mathbf{1 . 4 6}$ & 0 & 0.17 \\
\hline $\begin{array}{l}\text { Gaziantep'e yalnızca yiyecek-içecekler için } \\
\text { gelmem. (13) }\end{array}$ & 0 & 0.11 & -2 & -0.93 & $\mathbf{3}$ & $\mathbf{1 . 2 7}$ & 1 & 0.60 \\
\hline $\begin{array}{l}\text { Seyahatimde neler gördüğüm ne } \\
\text { yediğimden daha önemlidir. (24) }\end{array}$ & 0 & 0.16 & 0 & -0.46 & $\mathbf{1}$ & $\mathbf{0 . 7 9}$ & 0 & -0.29 \\
\hline $\begin{array}{l}\text { Yöresel yiyeceklerin nasıl pişirildiğini, } \\
\text { özelliklerini ve tarihini öğrenmek isterim. } \\
\text { (3) }\end{array}$ & 1 & 0.74 & 1 & 0.87 & $\mathbf{0}$ & $\mathbf{- 0 . 2 3 ^ { * }}$ & 0 & 0.49 \\
\hline $\begin{array}{l}\text { Gaziantep'teki yiyecek içecekler beni } \\
\text { buraya çekiyor. (27) }\end{array}$ & 3 & 1.17 & 4 & 1.58 & $\mathbf{- 1}$ & $\mathbf{- 0 . 5 1 *}$ & 2 & 1.08 \\
\hline
\end{tabular}

Q-SV (Q-Sort Value) ve Z-SCR (Z-Score) değerleri gösterilmektedir.

$\left(P<.05 ;{ }^{*}\right)$ ile gösterilenlerde anlamlllk $\left.P<.01\right)$

Tablo 8. Faktör 4'ün Ayırt Edici İfadeleri

\begin{tabular}{|l|l|l|l|l|l|l|l|l|l|}
\hline \multirow{2}{*}{ Terimler } & \multicolumn{2}{l|}{ Faktör 1 } & \multicolumn{2}{l|}{ Faktör 2 } & \multicolumn{2}{l|}{ Faktör 3 } & \multicolumn{2}{l|}{ Faktör 4 } \\
\cline { 2 - 10 } & $\begin{array}{l}\text { Q- } \\
\text { SV }\end{array}$ & $\begin{array}{l}\text { Z- } \\
\text { SCR }\end{array}$ & $\begin{array}{l}\text { Q- } \\
\text { SV }\end{array}$ & $\begin{array}{l}\text { Z- } \\
\text { SCR }\end{array}$ & $\begin{array}{l}\text { Q- } \\
\text { SV }\end{array}$ & $\begin{array}{l}\text { Z- } \\
\text { SCR }\end{array}$ & $\begin{array}{l}\text { Q- } \\
\text { SV }\end{array}$ & $\begin{array}{l}\text { Z- } \\
\text { SCR }\end{array}$ \\
\hline $\begin{array}{l}\text { Restorandaki yöresel yiyecek-içecek } \\
\text { deneyimi bana günlük rutinimden } \\
\text { uzaklaştığım hissettirir. (8) }\end{array}$ & 0 & -015 & 0 & -0.05 & 1 & 0.35 & $\mathbf{3}$ & $\mathbf{1 . 3 4 ^ { * }}$ \\
\hline $\begin{array}{l}\text { Gaziantep'e yalnızca yiyecek-içecekler } \\
\text { için gelmem. (13) }\end{array}$ & 0 & 0.11 & -2 & -0.93 & 3 & 1.27 & $\mathbf{1}$ & $\mathbf{0 . 6 0}$ \\
\hline $\begin{array}{l}\text { Gaziantep'teki yiyecek içecekleri sağlık } \\
\text { açısından güvenle tüketebilirim. (23) }\end{array}$ & 1 & 0.66 & 1 & 0.84 & 3 & 1.46 & $\mathbf{0}$ & $\mathbf{0 . 1 7}$ \\
\hline $\begin{array}{l}\text { Yöresel yiyecek-içecekler bana günlük } \\
\text { rutinimden farklı bir deneyim sunmaz. } \\
\text { (15) }\end{array}$ & -2 & -0.77 & 0 & -0.60 & -1 & -0.49 & $\mathbf{- 3}$ & $\mathbf{- 1 . 4 0 ^ { * }}$ \\
\hline $\begin{array}{l}\text { Gittiğim destinasyonda yalnizca önceden } \\
\text { bildiğim yiyecek-içecekleri denerim. (29) }\end{array}$ & 0 & -0.30 & -1 & -0.79 & -2 & -0.85 & $\mathbf{- 4}$ & $\mathbf{- 1 . 5 8 ^ { * }}$ \\
\hline
\end{tabular}

Q-SV (Q-Sort Value) ve Z-SCR (Z-Score) değerleri gösterilmektedir

$\left(P<.05 ;{ }^{*}\right)$ ile gösterilenlerde anlamlllık $P<.01$

"Bana göre yemek yemek sanat ve keyifiçerir. Yani sadece karnımı doyurmak yerine o yemekten haz almaya odaklanırım. Gittiğim şehirde bildiğim şeyleri tercih edeceksem yemek yemek için Gaziantep'e gelmezdim ve diğer şehirlerde de bulunan standart ürünler sunan herhangi bir restoranda karnımı doyurup çımaya 
odaklanırdım. Yemek yemek benim için bir sanat ve bu yüzden bildiğim yemeklerden ziyade bilmediklerimi tercih ederek yeni lezzetler öğrenirim." (E3)

"Bu ifadeyi-4'e yerleştirmemin nedeni bu fikre kesinlikle katılmamamdır. Ben Ankaralıyım ve Gaziantep'i ziyaret edip yemeklerinden yemeden gitmek olmaz. Kendi memleketimize ait yemekleri zaten sürekli yiyoruz, bence önemli olan yeniliklere açık olup yöresel lezzetler de denemek." (K19)

Tablo 9'da yer alan 9, 11, 14, 18, 21, 25, 31 ve 32 numaralı ifadeler her bir faktör altında toplanan katılımcıların fikir birliği sağladığı maddeleri göstermektedir. Tablo 9'a göre, 9 ve 32 numaralı ifadeler katılımcıların birbirine benzer fikirlere sahip olduğu ve en yakın değerler verdikleri cümleleri oluşturmaktadır. Örneğin, 18 numaralı ifade, 1., 2. ve 4. faktörler altında toplanan turistlerin genel olarak bu fikri olumlu bulduğu ve $Q$ dizgisinde +4 değeri verdikleri bir madde olmuştur. Bununla ilgili katılımcı görüşü aşağıda verilmektedir:

Tablo 9. Faktörler Arası İş Birliği

\begin{tabular}{|l|l|l|l|l|l|l|l|l|}
\hline & \multicolumn{2}{|l|}{ Faktör 1 } & \multicolumn{2}{l|}{ Faktö 2 } & \multicolumn{2}{l|}{ Faktör 3 } & \multicolumn{2}{l|}{ Faktör 4 } \\
\cline { 2 - 10 } Terimler & $\begin{array}{l}\text { Q- } \\
\text { SV }\end{array}$ & Z-SCR & $\begin{array}{l}\text { Q- } \\
\text { SV }\end{array}$ & Z-SCR & $\begin{array}{l}\text { Q- } \\
\text { SV }\end{array}$ & $\begin{array}{l}\text { Z- } \\
\text { SCR }\end{array}$ & $\begin{array}{l}\text { Q- } \\
\text { SV }\end{array}$ & Z-SCR \\
\hline $\begin{array}{l}\text { Gittiğim destinasyonda öncelikli } \\
\text { olarak yöresel yiyecek ve içecekleri } \\
\text { denerim. (9)* }\end{array}$ & 1 & 0.79 & 1 & 0.89 & 2 & 0.79 & 2 & 0.77 \\
\hline $\begin{array}{l}\text { Yemeğin görünümüne önem } \\
\text { vermem. (11) }\end{array}$ & -3 & -1.37 & -2 & -0.97 & -3 & -1.25 & -3 & -1.45 \\
\hline $\begin{array}{l}\text { Restoranin fiziksel özellikleri } \\
\text { (sıcaklık, koku, müzik, dekorasyon, } \\
\text { rahatlık) yediğim yemekle uyumlu } \\
\text { olmalıdır. (14) }\end{array}$ & 2 & 0.87 & 1 & 0.84 & 1 & 0.30 & 2 & 0.79 \\
\hline $\begin{array}{l}\text { Gastronomi turizmi yerel kültürü } \\
\text { anlamak için eşsiz bir fırsattır. (18) }\end{array}$ & 4 & 1.45 & 4 & 1.47 & 2 & 1.06 & 4 & 1.60 \\
\hline $\begin{array}{l}\text { Yediğim yemeğin görünüş olarak } \\
\text { iştah açı1 olması önemlidir. (21) }\end{array}$ & 3 & 1.41 & 2 & 1.03 & 4 & 1.64 & 3 & 1.31 \\
\hline $\begin{array}{l}\text { Restoran çalışanlarının menüdeki } \\
\text { yiyecek-içecekle ilgili tavsiyelerde } \\
\text { bulunması önemlidir. (25) }\end{array}$ & 2 & 1.04 & 1 & 1.02 & 2 & 0.99 & 1 & 0.58 \\
\hline $\begin{array}{l}\text { Gaziantep'in kendisini diğer } \\
\text { yörelerden ayıran eşsiz yiyecek } \\
\text { içecekleri vardır. (31) }\end{array}$ & 4 & 1.69 & 3 & 1.31 & 3 & 1.29 & 2 & 1.23 \\
\hline $\begin{array}{l}\text { Gittiğim destinasyondaki yediğim } \\
\text { yemeğin lezzeti önemlidir. (32)* }\end{array}$ & 3 & 1.28 & 3 & 1.33 & 4 & 1.66 & 3 & 1.25 \\
\hline
\end{tabular}

"Yediğim yemeğin tarihi, özellikleri ve ait olduğu kültürü öğrenmek ilgimi çeker. Mesleğim gereği gastronomi ile yakından ilgiliyim, ben de bu sektörün üst kıdem yöneticilerinden olduğum için gastronomi turizminin yerel kültürle kesinlikle bağlantılı olduğunu düşünüyorum. Bence Türkiye'nin en önemli turizm unsurlarından biri gastronomi çünkü her bölgenin kendine özgü lezzetleri var. Bu da gastronomiyi kültürle ilintili hale getiriyor." (E2)

Tablo 9 genel olarak değerlendirildiğinde, faktörler arasında fikir birliği sağlanan sekiz cümlenin yedi adeti olumlu ifadelerden, yalnızca biri olumsuz ifadeden oluşmaktadır. Bu olumsuz cümleye göre araştırmaya katılan gastronomi turistlerinin hepsinin yedikleri yiyeceklerin görünümüne önem verdikleri ortaya çıkmaktadır. Bunun yanı sıra belirlenen dört turist 
grubunun genel olarak beş ana boyut altında aşağıdaki alt boyutlara odaklandıkları belirlenmiştir:

- "Yiyecek" ana boyutunda, 'yemeğin lezzeti ve 'yemeğin görünüşü',

- "Restoran" ana boyutunda, 'fiziksel özellikler' ve 'personel'

- "Motivasyon" ana boyutunda, 'kültür',

- "Kişilik özellikleri" ana boyutunda, 'neofili',

- "Destinasyonun gastronomik imajı" ana boyutunda, 'ayırt edicilik' alt boyutu.

Analiz sonuçlarına göre birinci faktör altında yer alan turistler "Müdavim Turist" olarak ifade edilmiştir. Özelliklerine göre tanımlandığında müdavim turistler, fiyat-performans uyumu arayan, bu uyumu yakaladığında gittiği destinasyonun veya restoranın daimi ziyaretçisi haline gelen turistlerdir. Çünkü müdavimler, beklediği uyumu yakalama konusunda yediği yemek kadar o yemeği yediği ortamın fiziksel (ses, koku, ş̧ık vb.) özelliklerini de dikkate almaktadır. Yeniliğe karşı nötr bir grup olduğu için bu şartları sağlayan işletmelerden veya destinasyonlardan ayrilıp yeni yerler denemeyi pek tercih etmemektedirler.

Faktör 2 altında toplanan 13 turist ayırt edici özelliklerine göre incelendiğinde "Yöresellik Arayanlar" olarak isimlendirilmiştir. Bu turistlerin, menüde yer alan yöresel yiyecek-içecek olmasına dikkat eden ve bunlarla ilgili tanitıcı bilgiler arayan, Gaziantep'e yalnızca yiyecek içecek için gelebilecek gastronomi turistleri olduğu görülmektedir. Yöresellik arayanlar, bir destinasyona sadece oraya özgü yiyecek-içecekleri denemek için gidebilecek, gittiği bir restoranda aşina olduğu lezzetleri değil yöresel lezzetleri görmek ve öğrenmek isteyen turist grubu olarak ifade edilebilmektedir. Bir diğer deyişle bu grubun yeniliklere açık olduğunu söylemek mümkündür.

Bir diğer grubu oluşturan faktör 3'te 5 adet katılımcının fikir birliği sağladıkları ifadelere göre, bu gastronomi turistleri "Özgün Turist" olarak tanımlanmıştır. Bu grubu yediği yemeklerde sağlık etmenine dikkat eden ve Gaziantep yemeklerini güvenle tüketeceğini söyleyen, gittiği destinasyonda neler gördüğüne önem veren, yöresel yiyecek ve içeceklerin görünüş olarak iştah açıcı olmasına dikkat etmekle birlikte nasıl hazırlandığını öğrenme konusunda isteksiz görünen turistler oluşturmaktadır. Ayrıca bu faktörde yer alan turistler için yiyecek-içecek bir destinasyonun çekiciliğini sağlayan en önemli özellik olarak değerlendirilmemektedir. Özgün turist, çıktığ1 seyahatlerde neler gördügüne neler yediğinden daha çok önem veren, bir destinasyona gitmek için o yöreye ait lezzetleri tatmayı yeterli bir sebep olarak görmeyen bireylerdir. Ayrıca diğer gastronomi turist gruplarına nazaran yöresel yiyeceklerin özelliklerine, nasıl yapıldığına ve tarihine dair öğrenme istekleri de düşük derecededir. Bu sebeple de bu grup altındaki turistlerin, diğerlerine oranla gastronomi kültürüyle olan ilişkisi en zayıf görülen ve mutfak turizmine duyulan ilginin en zayıf derecede turistler olduğu söylenebilir.

Dördüncü faktörü oluşturan ve "Yenilik Arayanlar" olarak adlandırılan 9 katılımcının ifadeleri incelendiğinde gittikleri restoranlarda yöresel yiyecek-içecek denemenin günlük rutinden uzaklaştırdığını en yüksek değerde savunan turistler olduğu görülmektedir. Ayrıca bu turistler, gidilen destinasyonda kesinlikle bilinen lezzetlerin değil yeniliklerin ve denenmemiş tatların deneyimleme eğiliminde olan bir grubu temsil etmektedir. Bu gruptakiler gittiği destinasyonda yeniliğe açı olan, bilmediği lezzetler deneyimlemekten haz alan gastronomi turistleridir. Gastronomi turizmini ve yöresel yiyecekler denemeyi günlük rutin yaşamlarından farklı kılacak bir aktivite olarak değerlendirmektedirler.

Q metodolojisi kullanılarak taksonomi oluşturulması amaçlanan bu çalışmada, dört farklı gastronomi turisti ortaya konulmuştur. Bu çalışma kapsamında bu turistlerden her bir gruba dahil olanların taşıdıkları farklı özelliklerin bulunduğu ve bu turizm türüne katılmalarındaki sebeplerin birbirinden farklı olduğu görülmektedir. 


\section{SONUÇ ve ÖNERILLER}

Gastronomi turizmi alanında yapılan çalışmalar ele alındığında gastronomi turizmi ve alt dalları (şarap turizmi gibi) üzerine yapılan çalışmalar, gastronominin ve gastronomi turistlerinin özelliklerine yönelik araştırmalar gerçekleştirildiği görülmektedir. Gastronomi turistlerinin sınıflandırılmasına yönelik sınırlı sayıda araştırma yer almaktadır (Bekar ve Kılıç, 2014; Belpınar, 2014; Akbaba ve Kargiglioğlu: 2016; Şimşek ve Selçuk: 2018). Bu çalışmalarda nicel yaklaşımların sıklıkla kullanılması ile birlikte turistlerin sınıflandırılmasında uygun bir yöntem olan $Q$ metodun kullanıldığı sınırlı sayıda çalışma yer almaktadır (Tan vd., 2014).

Çalışma kapsamında elde edilen bulgulara göre "müdavim turist, yöresellik arayanlar, özgün turist, yenilik arayanlar" olmak üzere dört farklı turist grubu ortaya konulmuştur. Araştırma kapsamındaki yöresellik arayan ve yenilik arayan turist grupları, Şimşek ve Selçuk'un (2018) çalışmalarında belirlenen yöreselci ve yenilikçi turist grupları ile örtüşmektedir. Buna göre yöresellik arayanlar iki çalışmada da gidilen restoranda öncelikli olarak yöreye özgü yiyecekleri deneyimlemek istemeleri ile ayırt edici bir özellik oluşturmaktadırlar. Öte yandan yenilik arayanlar, gittikleri destinasyon ve/veya restoranda özellikle yeni lezzetleri deneyimlemeyi tercih eden bir grup olarak ortaya çıkmaktadır. Benzer şekilde Tan vd., (2014) 'nin yaratıcı turistler üzerine yaptıkları çalışmalarında ve Kraftchick vd., (2014) 'nin bira turistleri ile gerçekleştirdikleri çalışmalarında da yenilikçi bir turist grubundan söz etmek mümkün olmaktadır. Buna karşılık bu araştırmada belirlenen müdavim ve özgün turist gruplarının farklı özelliklere sahip bireylerden oluştuğunu söylemek mümkündür. Fiyat-performans uyumuna öncelik veren müdavim turistler bu uyumu yakaladıkları takdirde gittikleri destinasyon ve/veya restorana gitmeye devam etmekte ve yeni yerler denemeyi gerekli görmemektedir. Frolova vd., (2017) 'nin Rus turistlerin streotipleri ile ilgili yaptığ 1 sosyolojik analizlerinde fiyat ile ilgili olarak bu çalışmadaki fiyat-performans arayan turistler ile benzer noktalar olduğu görülmektedir. Çalışmada turistlerin destinasyon seçiminde etkili olan ana faktörlerin fiyat, konfor ve iklim olduğu ve gelir seviyesine bağlı olarak tercih edilen bu faktörlerin elenebileceği göz önünde bulundurulmuştur. Örneğin fiyatı önemseyen düşük gelirli turistlerin, kendilerine en uygun fiyatı seçerken aşırı konfora önem vermediği görülmüştür, fiyat ve iklim uygunsa konfor seviyesini düşürmeye hazır oldukları görülmüştür. Özgün turist için yiyecek-içecek tek başına bu gruptaki bireyleri bir destinasyona çekecek kadar etkili bir unsur olmamaktadır. Diğer turist gruplarına kıyasla gastronomik unsurlara ilgisi en az olan bu grup için gidilen destinasyondaki diğer kültürel unsurlar öncelikli sırada yer almaktadır. Yun vd., (2011)'nin mutfak deneyimlerine göre turistleri dört gruba ayırdığı çalı̧masında yer alan ilgisiz mutfak turisti ile özgün turistin benzer özelliklerde olduğunu söylemek mümkündür.

Araştırma sonuçlarının literatüre ve uygulamaya yönelik katkılarından söz etmek mümkündür. Uluslararası literatürde yaratıcı turizm gibi diğer turizm türlerine yönelik çalışmalar görülmekle birlikte gastronomi turistlerinin sinıflandırılmasında $Q$ metodolojinin kullanılmadığ belirlenmiştir. Q metodolojinin nicel ve nitel araştırma yöntemlerinin avantajlarını bir arada sunmakta, araştırmaya katılanların subjektif bilgilerine ulaşılarak bir sınıflandırma yapılmasına olanak tanımaktadır.

Araştırmanın belirlenen turist gruplarının özelliklerine bağlı olarak yiyecek-içecek işletmelerine sunduğu öneriler aşağıda yer almaktadır:

- Gastronomi turistlerinin yiyecek içeceğe ilgileri göz önünde bulundurulduğunda resmi ve/veya özel kurumlar tarafından yöreye has lezzetlerin sunulduğu ve yemeklerin yapılışlarının öğretildiği işletme sayılarının artırılması gerekmektedir.

- Müdavim turist tipine odaklanmak isteyen işletmeler, bu grubun yeniliğe karşı nötr olmasından dolayı, aynı hizmeti veya aynı ürünü belirli bir standarda göre sunmalı, 
restoranlarda fiziksel koşullara ve atmosfere dikkat etmelidir. Bu gruptaki turistler fiyatperformans uyumu aradıkları ve buna göre restoran seçiminde bulundukları için menüde uygun fiyatların olmasına dikkat edilmelidir.

- Yöresellik arayanlar gittikleri restoranda menülerde yöresel ürünlerin olup olmadığına dikkat eden turist gruplarıdır. Bu sebeple yöresel mutfağı ile ön plana çıkmak isteyen bölgelerde restoranlar, menülerinde yöreselliği ön planda tutmalı ve bunlara ilişkin tanıtıcı bilgilere yer vermelidir.

- Özgün turist, gittiği destinasyonda neler gördüğüne daha çok önem veren turist gruplarıdır. Bu gruba odaklanan yöreler gastronomik unsurlarının yanı sıra bölgenin diğer kültürel ve tarihi zenginliklerini de tanıtmalı ve pazarlama faaliyetlerinde bu noktalara da önem vermelidir.

- Yenilik arayanların en belirgin özelliği denenmemiş lezzetlere odaklanmalarıdır. Gastronomi kültüründeki farklılıkları ile tanınmak isteyen destinasyonların bu turistleri yeni ve farklı tatlarıyla şaşırtması ve pazarlama çalışmalarında bunu vurgulamaları gerekmektedir.

Araştırmanın kuramsal ve uygulamaya katkılarının yanı sıra bazı sınırlılıkları bulunmaktadır. Bu çalışma Gaziantep iline gelen ve Mutfak Sanatları Merkezini ziyaret eden gastronomi turistleri ile sınırlıdır. Araştırma bulguları ile genelleme yapılamaz. Araştırma yöntemi olarak $Q$ metodoloji kullanılmıştır. Daha fazla sayıda gastronomi turistinin görüşlerine ulaşmak için nicel yöntemlerden yararlanılabilir. Bu çalışmada gastronomi turistine odaklanılmaktadır. Gelecek çalışmalarda farklı turizm türlerine katılan turistler üzerine de taksonomi çalışması gerçekleştirilebilir.

\section{KAYNAKÇA}

Akbaba, A. ve Kargiglioglu, Ş. (2016). Yerli Gastro Turistlerin Eğitim Seviyeleri ve Yaş Gruplarına Göre Destinasyondaki Gastronomi Turizmi Etkinliklerine Katılımları: Gaziantep'i Ziyaret Eden Gastro Turistler Üzerine Bir Araştırma, Journal of Tourism and Gastronomy Studies, 4(1): 87-95.

Akkuş, G. (2017). Kış Turizmi Destinasyonunda Yaşanan Unutulmaz Turizm Deneyimleri: Kültürlerarası Karşılaştırma, Seyahat ve Otel İşletmeciliği Dergisi, 14(3): 223-236.

Bayrakcı, S. ve Akdağ, G. (2015). Yerel Yemek Tüketim Motivasyonlarının Turistlerin Tekrar Ziyaret Eğilimlerine Etkisi: Gaziantep'i Ziyaret Eden Yerli Turistler Üzerine Bir Araştırma, Anatolia: Turizm Araştırmaları Dergisi, 27(1): 96-110.

Bekar, A. ve Kılıç, B. (2014). Turistlerin Gelir Düzeylerine Göre Destinasyondaki Gastronomi Etkinliklerine Katılımları, Uluslararası Sosyal ve Ekonomik Bilimler Dergisi, 4(1): 19-26.

Belpınar, A. (2014). Gastronomi Turizmine Yönelik Turist Görüşlerinin Kültürlerarası Karşılaştırılması: Kapadokya Örneği, Yayımlanmamış Yüksek Lisans Tezi, Muğla Sıtkı Koçman Üniversitesi, Muğla.

Birdir, K. ve Akgöl, Y. (2015). Gastronomi Turizmi ve Türkiye'yi Ziyaret Eden Yabancı Turistlerin Gastronomi Deneyimlerinin Değerlendirilmesi, İşletme ve İktisat Çalı̧̧maları Dergisi, 3(2): 57-68.

Caber, M. and Albayrak, T. (2016). Push or Pull? Identifying Rock Climbing Tourists' Motivations, Tourism Management, 55: 74-84.

Chang, R. C. Y. and Mak, A. H. N. (2018). Understanding Gastronomic Image from Tourists' Perspective: A Repertory Grid Approach, Tourism Management, 68: 89-100.

Cankül, D. (2011). Otel Seçimine Etki Eden Faktörlerden Biri Olarak Dini Hayat Tarzlarının Etkisi Üzerine Bir Alan Araştırması, Yayımlanmamış Yüksek Lisans Tezi, Gazi Üniversitesi, Ankara.

Charters, S. and Ali-Knight, J. (2000). Who is the Wine Tourist, Tourism Management, 23(3): 311319. 
Crompton, J.L. and McKay, S.L. (1997). Motives of Visitors Attending Festival Events, Annals of Tourism Research, 24(2): 425-439.

Demir, F. ve Kul, M. (2011). Modern Bir Araştırma Yöntemi Q Metodu. (1. Basım), Ankara: Adalet Yayınevi.

Fodness, D. (1994). Measuring Tourist Motivation, Annals of Tourism Research, 21: 555-581.

Frolova, E.V., Rogach, O.V., Kabanova, E.E., Medvedeva, N.V. and Shimanskaya I.Y. (2017). Tendencies and Prospects of Tourism Industry in Russia: Sociological Analysis of Stereotypes Among Population During Tourism Trips, European Research Studies Journal, 20: 308-320.

Guzman, L.T., Hernandez-Mogollon, J.M. and Di-Clemente, E. (2014). Gastronomic Tourism as an Engine for Local and Regional Development, Regional and Sectoral Economic Studies, 14(1): 92-102.

Hsu, C.H.C. and Huang, S. (2007). Travel Motivation: A Critical Review of the Concept's Development, (Editors) Woodside, A.G. and Martin, D.: Tourism Management: Analysis, Behaviour and Strategy, (pp.14-27) Massachusetts: Boston College.

Hudson, S. (2008). Tourism and Hospitality Marketing: A Global Perspective. London: Sage Publications Inc.

Kayar, Ç.H. (2008). Tatil Kararı Verme Tarzına Dayalı Bir Tipoloji, Anatolia: Turizm Araştırmaları Dergisi, 19(1): 84-92.

Kesici, M. (2012). Kırsal Turizme Olan Talepte Yöresel Yiyecek ve İçecek Kültürünün Rolü, KMÜ Sosyal ve Ekonomik Araştırmalar Dergisi, 14(23): 33-37.

Kim, E.Y.J. (1997). Korean Outbound Tourism: Pre-Visit Expectations of Australia, Journal of Travel and Tourism Marketing, 6(1): 11-19.

Kim, Y.G. and Eves, A. (2012). Construction and Validation of a Scale to Measure Tourist Motivation to Consume Local Food, Tourism Management, 33(6): 1458-1467.

Kim, S.S., Lee, C.K. and Klenosky, D. (2003). The Influence of Push and Pull Factors at Korean National Parks, Tourism Management, 24:169-180.

Klenosky, D. (2002). The "Pull" of Tourism Destinations: A Means-End Investigation, Journal of Travel Research, 40: 385-395.

Koçak, M. (2010). The Application of Q Methodology to Generate a Functional Typology of Terrorist Organizations in Turkey, Yayınlanmamış Doktora Tezi, Kent State University, Ohio.

Kraftchick, J. F., Byrd, E. T., Canziani, B. and Gladwell, N. J. (2014). Understanding Beer Tourist Motivation, Tourism Management Perspectives, 12: 41-47.

Mason, M. C. and Paggiaro, A. (2009). Celebrating Local Products: The Role of Food Events, Journal of Foodservice Business Research, 12(4): 364-383.

Mo, C., Howard, D.R., and Havitz, M.E. (1993). Testing an International Tourist Role Typology, Annals of Tourism Research, 20(2): 319-335.

Pizam, A., Neumann, Y. and Reichel, A. (1979). Tourist Satisfaction: Uses and Misuses, Annals of Tourism Research, 6(2): 195-197.

Plog, S. (2001). Why Destination Areas Rise and Fall in Popularity, an Update of a Cornell Quarterly Classic, Cornell Hotel and Restaurant Administration Quarterly, 42(3): 13-24. 
Prebensen, N. K., Woo, E. and Uysal, M. S. (2014). Experience Value: Antecedents and Consequences, Current Issues in Tourism, 17(10): 910-928.

Ryan, C. (1998). The Travel Career Ladder: An Appraisal, Annals of Tourism Research, 25(4): 936957.

Sirakaya, E. and McLellan, R.W. (1997). Factors Affecting Vacation Destination Choices of College Students, Anatolia: An International Journal of Tourism and Hospitality Research, 8(3): 31-44.

Sorokina, A. (2016). Typology of Gastronomy Tourists and Tourism, Master of Science Thesis, International Hellenic University, Thessaloniki, Greece.

Şimşek, A. ve Selçuk, G.N. (2018). Gastro-Turistlerin Tipolojisinin Belirlenmesi: Gaziantep Ölçeğinde Bir Araştırma, Uluslararası Türk Dünyası Turizm Araştırmaları Dergisi, 3(1): 28-43.

Tan, S. K., Luh, D.B. and Kung, S.F. (2014). A Taxonomy of Creative Tourists in Creative Tourism, Tourism Management, 42: 248-259.

Tellioğlu, S. (2021). Türk ve Alman Turistleri Tatile İten ve Çeken Faktörlerin Analizi, Alanya Akademik Bakış Dergisi, 5(1): 287-299.

TÜRSAB (2015). Gastronomi Turizmi Raporu, https://www.tursab.org.tr/dosya/12302/tursabgastronomi-turizmi raporu_12302_3531549.pdf [Erişim Tarihi: 18.03.21].

UNESCO (2018). Yaratıcı Şehirler Ağı, http://www.unesco.org.tr/Pages/519/129/ [Erişim Tarihi: 20.04.2018].

UNWTO (2012). Birleşmiş Milletler Dünya Turizm Örgütü, http://www2.unwto.org/content/about-us-5 [Erişim Tarihi: 10.12.18].

Ustasüleyman, T. ve Eyüboğlu, K. (2010). Bireylerin İnternet Bankacılığını Benimsemesini Etkileyen Faktörlerin Yapısal Eşitlik Modeli ile Belirlenmesi, BDDK Bankacıllk ve Finansal Piyasalar, 4(2): 11-38.

Üner, E.H. (2014). Her Şey Dahil Sistemde Türkiye Gastronomi Turizmi Potansiyelinin Değerlendirilmesi, Yayınlanmamış Yüksek Lisans Tezi, Atılım Üniversitesi, Ankara.

Üzümcü, O.O. (2018). Gastronomi Kültürü ve Gastronomi Turizmi Açısından Likya Bölgesini Ziyaret Eden Turistler Üzerine Bir İnceleme, Yayınlanmamış Yüksek Lisans Tezi, Gaziantep Üniversitesi, Gaziantep.

World Food Travel Association (2006). Food Tourism and Economic Impact, https://worldfoodtravel.org/what-is-food-tourism-definition-food-tourism/ [Erişim Tarihi: 04.11.2018].

XSIGHT (2017). Türkiye'nin Gastronomi Turizm Raporu, https://www.xsights.co.uk/tr/turkiyenin-gastronomi-turizmi-raporu-aciklandi-7636/ [Erişim Tarihi: 20.04.2018].

Yeşilyurt, H. ve Arıca, R. (2018). Mutfak Müzesi Ziyaretçilerinin Deneyimlerinin İncelenmesi: Emine Gögü̈ş Mutfak Müzesi Örneği, Türk Turizm Araştırmaları Dergisi, 2(1): 60-70.

Yoon, Y. and Uysal, M. (2005). An Examination of the Effects of Motivation and Satisfaction on Destination Loyalty: A Structural Model, Tourism Management, 26(1): 45-56.

Yousefi, M. and Marzuki, A. (2012). Travel Motivations and the Influential Factors: The Case of Penang, Malaysia, An International Journal of Tourism and Hospitality Research, 23(2):169-176. 
Yun, D., Hennessey, S. M. and MacDonald, R. (2011). Understanding Culinary Tourists: Segmentations Based on Past Culinary Experiences and Attitudes toward Food-related Behaviour. International CHRIE Conference, 29 July 2011, University of Massachusetts, ABD. 